\title{
Menemukan Makna Hidup dengan Forgiveness Studi pada Siswa Binaan Remaja di Lembaga Pemasyarakat Anak Pekanbaru
}

\author{
Dwita Razkia $^{1}$, Ajeng Safitri ${ }^{2}$, Santoso ${ }^{3}$ \\ 1,2,3Psikologi Islam, Fakultas Studi Islam, Universitas Muhammadiyah Riau \\ Jl. Tuanku Tambusai Ujung, Pekanbaru, Indonesia \\ dwitarazkia@umri.ac.id
}

\begin{abstract}
Abstrak
Menjadi narapidana bukanlah sesuatu yang mudah di lingkungan masyarakat, khususnya usia remaja. Munculnya stereotype negatif dari masyarakat dapat mempengaruhi keadaan psikologis remaja ketika melanjutkan hidup setelah keluar dari penjara. Pemaafan yang ada pada diri dibutuhkan agar dapat mengatasi rasa bersalah akibat dari perbuatannya dimasa lalu. Kualitas kebermaknaan hidup yang dimiliki oleh narapidana remaja dapat menjadi motivasi untuk melanjutkan hidupnya di masa yang akan datang. Penelitian ini bertujuan untuk mengetahui hubungan antara forgiveness dengan kebermaknaan hidup pada siswa binaan yang ada di LPKA Tk.II kota Pekanbaru. Penelitian ini menggunakan skala meaning in Life queationnaire (20 aitem) dan skala Heartland Forgiveness Scale (HFS) (18 aitem) dengan metode pengumpulan data kuantitatif yang melibatkan seluruh siswa binaan sebanyak 70 orang remaja dengan rentang usia 13 - 18 Tahun yang ada di LPKA Tk.II kota Pekanbaru. Analisis data dari hasil penelitian menunjukkan terdapat hubungan positif yang cukup signifikan antara Forgiveness dengan tingkat kebermaknaan hidup remaja $(r=0.662, p=0.000)$, yang artinya semakin baik pemaafan dalam diri siswa binaan maka semakin baik juga kebermaknaan hidupnya.
\end{abstract}

Kata kunci: Pemaafan; Kebermaknaan Hidup; Lapas; Narapidana

\begin{abstract}
Being a prisoner is not easy in society, especially in adoLescence. The emergence of negative stereotypes from society can affect the psychological state of adolescents after out from the prison. Forgiveness is needed in order to overcome the guilt that results from past actions. The quality of Life meaningfulness possessed by teenage prisoners can be a motivation to continue their life in the future. This study aims to determine the relationship between forgiveness and meaningfulness of Life in the assisted students at LPKA Tk.II Pekanbaru city. This study uses a meaning in Life queuing scaLe (20 items) and the Heartland Forgiveness Scale (HFS) scale (18 items) with quantitatif analysis method involving 70 assisted students aged 13-18 years in LPKA Tk. II Pekanbaru city. The research results showed that there was a significant positive relationship between Forgiveness and the meaning of adolescent life $(r=0.662, p=0.000)$, which means that the better the forgiveness they have, the better the meaning of their life.
\end{abstract}

Keywords: Forgiveness; Meaningfullness; Prison

\section{PENDAHULUAN}

Sebagai individu, dalam tahapan perkembangannya, remaja akan memilih tentang jati dirinya, siapa dirinya, bagaimana dirinya, serta tujuan yang akan diraih (Santrock, 2019). Dalam proses ini remaja cenderung terlibat dalam masalah ataupun yang sering kita istilahkan kenakalan remaja. Lingkup kenakalan remaja mencakup tingkah laku yang tidak dapat diterima secara sosial hingga tindakan criminal (Astuti \& Marettih, 2018). Tidak jarang 
remaja terjerumus pada hal yang negatif, dan setelahnya melakukan tindakan atau perilaku yang tidak semestinya (Santrock, 2011). Pidana penjara dapat diberikan pada remaja sebagai sanksi dari tindakan negatif yang berujung pada tindak kriminal. Berdasarkan data yang ada di Dirjen Permasyarakatan, Dupkumham, jumlah remaja di Indonesia yang berhadapan dengan hukum cukup banyak, mencapai kurang lebih 78.000 kasus yang tersebar di setiap provinsi dan data ini setiap tahunnya meningkat a (Afdal, 2010).

Pada Lembaga Pemasyarakat Anak Tk.II kota Pekanbaru, tepatnya pada Lapas Anak Tk.II ini terdapat 70 orang remaja yang sedang menjalani hukuman atau binaan karena perbuatan negatif yang telah lakukan. Berdasarkan wawancara singkat dengan kepala Lapas, perilaku negatif para siswa binaan sebagian besar muncul akibat dari lingkungan dan kurangnya penanaman nilai agama pada remaja tersebut. Pidana penjara tidak hanya mengakibatkan perampasan kemerdekaan, tetapi juga menimbulkan akibat negatif terhadap hal-hal yang berhubungan dengan dirampasnya kemerdekaan itu sendiri (Lubis \& Maslihah, 2012). Hukuman penjara dapat memunculkan stigma-stigma negatif, seperti labeling "orang jahat" yang tetap melekat pada identitas individu walaupun sudah berubah dan menjadi pribadi yang positif. (Adista, 2015)juga mengungkapkan bahwa setelah keluar dari lapas, narapidana anak tidak lagi diterima oleh masyarakat bahkan dikucilkan, dan hal ini menjadi kendala bagi narapidana remaja yang betul-betul ingin bertaubat (Akhyar et al., 2014).

Pengalaman hidup di penjara dapat menyebabkan terjadinya penurunan derajat dan harga diri manusia (Arista, 2017) Penelitian oleh Evans et al., (2007) terhadap 105 narapidana remaja di Amerika menunjukkan bahwa mereka mengalami beberapa gejala gangguan pasca trauma yaitu adanya ingatan-ingatan yang menganggu (46\%) dan memiliki pikiran terus menerus terkait dengan perilaku kriminal yang mereka lakukan (38\%). Fristian et al., (2020) mengatakan mantan narapidana sering menemukan hambatan kembali ke kehidupan masyarakat karena predikat negatif untuk seorang narapidana. Hal ini senada dengan Azani (2012)yang menyebutkan bahwa proses peralihan mantan narapidana menuju lingkungan masyarakat sebenarnya sangat sulit karena kehadiran stereotype tersebut. Situasi ini menimbulkan rasa trauma untuk kembali membaur di kehidupan masyarakat, serta dikhawatirkan akan menyebabkan mantan narapidana remaja sulit bersosialisasi di lingkungan masyarakat dan mengulangi kembali melakukan tindakan kriminal. Pembinaan dan perlindungan yang di berikan kepada narapidana remaja haruslah di perhatikan sedini mungkin agar terhindar dari munculnya kembali perilaku negatif dan perbuatan yang dapat merugikan dirinya sendiri setelah keluar dari lapas.

Disisi lain situasi di dalam penjara dapat memberikan ruang untuk berpikir dan menyesali perbuatannya sehingga tidak mengulangi kesalahan yang sama di masa depan. Pada masa itu, Narapidana perlu menemukan makna untuk melanjutkan kehidupan bermasyarakat, yang akan berdampak pada kebahagiaan individu. Kebahagiaan tersebut adalah hasil dari segala usaha setelah melakukan kegiatan-kegiatan yang bermakna (Bastaman, 2007). Kebermaknaan hidup dapat menjadikan narapidana merasakan arti hidupnya, termotivasi untuk lebih baik lagi, dan semangat dalam menjalani hidupnya meskipun harus berada dalam tahanan dalam waktu yang panjang. Pada penelitian yang dilakukan (Soleh, 2001) menyebutkan bahwa kebermaknaan hidup adalah faktor yang memiliki pengaruh besar terhadap kesehatan jiwa, daya tahan terhadap stress, dan tingkat harga diri remaja. Hal ini berkesinambungan dengan penelitian dari (Brassai et al., 2011) yang mengatakan kesehatan psikologis remaja sangat erat kaitannya dengan makna dalam kehidupan.

Salah satu cara memaknai kebermaknaan hidup dengan baik adalah dengan memaafkan 
segala hal yang menyakitkan dan yang mengganjal hati mereka. Memaafkan atau forgiveness adalah suatu proses (hasil dari proses) yang melibatkan perubahan emosi dan sikap kepada orang lain atau situasi (American Psychological Association, 2006). Remaja harus mampu untuk memaafkan diri pribadinya yang telah membuat kesalahan dimasa lalu dan memaafkan orang-orang atau situasi yang membuatnya melakukan kesalahan tersebut. Pemaafan berkaitan dengan menghilangkan sesuatu yang negatif sekaligus menumbuhkan sesuatu yang positif (Nashori, 2011). Pemaafan diartikan kesediaan untuk meninggalkan hal-hal yang tidak menyenangkan yang bersumber dari hubungan interpersonal dengan orang lain dan menumbuh kembangkan pikiran, perasaan, dan hubungan interpersonal yang positif dengan orang lain yang melakukan pelanggaran secara tidak adil (Nashori, 2011). Remaja yang memiliki pemaafan yang baik diharapkan dapat memaknai kehidupannya dengan baik. Penelitian yang dilakukan oleh (Datu, 2014) menyebutkan bahwa memaafkan berperan penting dalam menentukan kebahagiaan pada remaja yang ada di Filipina. Individu yang memaafkan dapat mengontrol dan melepaskan stress yang disebabkan adanya emosi dan pikiran negatif sehingga individu memiliki kemampuan dalam mengelola emosi yang berperan penting dalam proses memaafkan (Rey \& Extremera, 2014). Penelitian yang dilakukan oleh (Damayanti, 2012) menunjukkan pemaafan dapat tercipta dengan mempertahankan sikap-sikap positif yang ada dan mengembangkan diri kearah positif. Pengembangan diri ini menjadikan remaja secara optimal menjalankan fungsi-fungsinya dalam hidup dan mencapai keadaan sejahtera secara psikologis. Pemaafan merupakan cara yang dapat dilakukan dalam penyesuaian diri dengan lingkungan, sehingga dapat terjalin hubungan yang positif antara diri dan lingkungan sosial (Toussaint \& Webb, 2005).

Penelitian yang mengangkat sampling pada narapidana khususnya remaja atau anak sudah banyak dilakukan di Indonesia (Arista, 2017; Astuti \& Marettih, 2018; Azani, 2012; Zuanny \& Subandhi, 2017). Seperti penelitian oleh Ferawati dan Rahmandani (2020) yang menyatakan adanya hubungan positif yang signifikan antara pemaafan diri dengan regulasi emosi pada anak didik di LPKA Kelas I Kutoarjo dan Kelas II Yogyakarta. Penelitian mengenai korelasi kebermaknaan hidup dan pemaafan pada remaja telah dilakukan oleh Astuti (2018), namun sampling yang diambil adalah remaja yang tinggal di Panti Asuhan kota Pekanbaru. Sementara penelitian Zuanny dan Subandhi (2016) menunjukkan bahwa terapi pemaafan akan membantu individu yang ada di lapas untuk menemukan makna hidup. Berdasarkan uraian di atas setelah selesai menjalani hukuman, Narapidana akan kembali ke lingkungan masyarakat dan memulai kehidupan baru berdampingan dengan masyarakat yang mungkin mayoritas akan memberikan stigma negatif terhadap narapidana. Remaja yang dapat memaafkan diri sendiri, memaafkan orang lain, dan memaafkan situasi yang dihadapinya dapat mengubah kondisi psikologis kearah yang lebih positif, lebih percaya diri di kehidupan yang akan datang, serta memiliki hubungan yang baik dengan lingkungannya. Situasi ini dapat membuat narapidana remaja lebih menghargai kehidupannya dan tidak mengulangi melakukan tindakan kriminal. Oleh karena itu peneliti tertarik untuk melihat hubungan antara Pemaafan dengan Kebermaknaan Hidup pada remaja yang menjadi siswa binaan di LPKA Tk.II kota Pekanbaru.

Sebagai tambahan, saat ini di Lembaga Pemasyarakatan Anak Kelas II Pekanbaru belum memiliki kegiatan ataupun program pendampingan dalam bidang psikologi. sehingga hasil dari penelitian ini diharapkan dapat menjadi salah satu referensi bagi LPKA untuk menghadirkan solusi pendampingan psikologi bagi siswa binaan sehingga mereka dapat membangun kualitas hidup menjadi lebih bermakna dan membangun kualitas diri yang lebih 
sehat secara psikologis sebagai dasar dalam memulai kehidupan sosialnya setelah keluar dari lembaga pemasyarakatan.

\section{METODE}

Responden populasi dalam penelitian ini berjumlah 70 orang remaja laki-laki yang dinamai siswa binaan di Lembaga Pemasyarakatan Anak KeLas II Pekanbaru dengan usia remaja 13 sampai dengan 18 tahun. Penelitian ini menggunakan metode analisis kuantitatif dengan pendekatan korelasional menggunakan skala pemaafan dan skala kebermaknaan hidup. Penelitian ini menggunakan Heartland Forgiveness Scale (HFS) yang dikembangkan oLeh Thompson et al., (2005). Skala HFS telah diadaptasi kedalam bahasa Indonesia dan digunakan pada penelitian Astuti (2018). Skala HFS ini berisikan 18 pernyataan yang mengukur pemaafan terhadap diri sendiri (6 item), mengukur pemaafan terhadap orang Lain (6 item) dan mengukur pemaafan terhadap situasi yang dihadapi (6 item). Skala HFS memiliki nilai reliabilitas sebesar 0,839 .

Skala yang kedua yang digunakan yaitu Skala meaning in Life questionnaire dari (Steger, 2010) sebagai skala untuk mengukur kebermaknaan hidup dengan jumlah pernyataan 20 item. Skala meaning in Life questionnaire juga telah diadaptasi kedalam bahasa Indonesia Nilai reliabilitas pada skala meaning in Life questionnaire adalah sebesar 0.885 (Astuti, 2018). Kedua skala ini menggunakan metode seLf repport dengan pilihan jawaban terdiri dari Sangat Tidak Setuju (1), Tidak Setuju (2), Setuju (3), Sangat Setuju (4). Teknik pengambilan data yang digunakan dalam penelitian ini yaitu sampling jenuh dengan mengambil sample yang mewakili jumlah populasi dikarenakan jumlah sample dalam populasi kurang dari 100 orang.

\section{HASIL}

Data penelitian ini diperoleh dalam bentuk kuesioner yang diberikan kepada 70 orang siswa binaan berjenis kelamin Laki-Laki dengan rentang usia 13 - 18 tahun di Lapas khusus Anak Tk.II kota Pekanbaru. Analisis data penelitian ini telah melalui uji normalitas dan uji linieritas dengan nilai normalitas untuk variabel kebermaknaan hidup (0.147) dan nilai normalitas untuk variabel pemaafan (0.189), sedangkan nilai linieritasnya $(F=6.075, \mathrm{p}>0.05)$.

Analisis data uji hipotesis menggunakan analisis korelasi dengan analisis uji Pearson Product Moment. Nilai korelasi pemaafan dengan kebermaknaan hidup adalah 0.662 dengan nilai signifikasi $0.000<0.05$. Hasil ini menunjukkan terdapat hubungan positif yang signifikan antara pemaafan dan kebermaknaan hidup dari remaja siswa binaan di Lapas Khusus Anak Tk.II kota Pekanbaru. Nilai keterkaitan hubungan antara pemaafan dan kebermaknaan hidup yang dimiliki adalah sebesar 0.662 dan keeratannya kuat. Hasil uji hipotesis penelitian memperlihatkan adanya hubungan antara pemaafan dengan kebermaknaan hidup dari siswa binaan di Lapas Tk.II Kota Pekanbaru.

\section{DISKUSI}

Remaja yang mampu memaafkan dapat mencapai makna hidupnya dengan baik walaupun mereka memiliki masa lalu yang negatif ataupun berada dalam lingkungan yang negatif. Hasil ini selaras dengan penelitian yang telah dilakukan sebelumnya yaitu penelitian Rahmania et al., (2021) dengan hasil penelitian yang menyatakan bahwa terdapat pengaruh yang cukup signifikan antara pemaafan dan kebermaknaan hidup pada remaja yang menjadi korban perceraian orang tuanya. Hal yang sama juga didapatkan pada penelitian (Astuti, 110

Dwita Razkia-Forgiveness dengan Tingkat Kebermaknaan Hidup Siswa Binaan LPKA 
2018) dengan hasil penelitian terdapat hubungan yang positif antara pemaafan dengan kebermaknaan hidup pada remaja yang tinggal di panti asuhan.

Hasil pada penelitian ini menunjukkan terdapat hubungan positif yang cukup signifikan antara pemaafan dengan kebermaknaan hidup yang dimiliki oleh siswa binaan di Lapas Tk.II kota Pekanbaru. Dalam penelitian Zuanny dan Subandhi (2016) diperoleh hasil penelitian bahwa terapi pemaafan dapat memberikan pemahaman dan keterampilan koping yang adaptif pada Warga Binaan Pemasyarakatan (WBP) untuk berdamai terhadap diri sendiri, orang lain, dan situasi yang menekan serta mereduksi berbagai emosi negatif sehingga kebermaknaan hidup meningkat. Hubungan forgiveness dengan kebermaknaan hidup juga telah dibahas pada penelitian Yalçın dan Malkoç (2015), hasil penelitian menunjukkan bahwa harapan dan pemaafan sepenuhnya dapat menjadi mediasi hubungan antara kebermaknaan hidup dengan subjective well-being. Penelitian tersebut mengungkapkan bahwa forgiveness dapat menjadi mediator untuk meningkatkan kebermaknaan hidup individu. Penelitian lain mengungkapkan mengenai hubungan forgiveness dan kebermaknaan hidup pada remaja dengan analisis hasil penelitian yang diperoleh membuktikan bahwa nilai pemaafan memiliki hubungan yang signifikan secara statistik dengan makna dalam kehidupan (Glaz, 2019). Remaja yang memiliki kontrol emosi rendah akan sulit dalam proses memaafkan dan membutuhkan waktu lebih lama dalam memaafkan baik itu memaafkan orang lain maupun memaafkan dirinya sendiri, dan menghambat remaja untuk merasakan kebahagiaan dalam dirinya. Hal ini terjadi dikarenakan remaja perlu untuk beradaptasi dengan permasalahan yang dihadapi. Al-jauziyah (2005) mengatakan bahwa manusia yang dapat menggunakan strategi yang berorientasi pada masalah dapat meningkatkan makna hidup, kebahagiaan dan menurunkan tingkat stres.

Perubahan perilaku dari pelanggaran menjadi perilaku yang menghindari perasaan negatif, atau kurangnya motivasi negatif dalam diri seseorang dinamakan sebagai pemaafan (McCullough, 2000). Pemaafan muncul dalam diri seseorang ketika sudah adanya kemampuan dan kemauan melakukan interaksi sosial dan menjalin hubungan dengan lingkungan sosial yang telah menyakiti dirinya. Memaafkan bukan hanya memberi maaf secara langsung dengan menerima kesalahan orang lain tetapi ada proses yang dihadapi sampai mencapai pemaafan tersebut. Individu yang telah memaafkan dapat mengendalikan dan membuang emosi dan pikiran negatif juga melepaskan stress yang diakibatkan terjadinya perceraian antar orang tua, sehingga anak yang memiliki kemampuan dalam mengelola emosi yang berperan penting dalam proses tercapainya pemaafan (Rey \& Extrema, 2014).

Penelitian yang dilakukan oleh UYSAL et al., (2014) menemukan bahwa kebahagiaan dan kesehatan yang dimiliki remaja memiliki hubungan terhadap kemampuan memaafkan yang mereka miliki, yangmana remaja yang mudah memaafkan akan lebih banyak merasakan kebahagiaan. Kondisi kesehatan pada remaja yang mudah memaafkan lebih baik dibandingkan remaja yang sulit memaafkan. Pernyataan ini diperkuat oleh Toussaint dan Webb (2005) yang mengatakan memaafkan dapat memperbaiki kondisi kesehatan yaitu kesehatan mental, dan juga kesehatan secara spiritual. Dengan memaafkan, remaja akan lebih sehat dan merasa bahagia dalam kehidupannya. Kebahagiaan muncul melalui pengalaman individu dalam mengendalikan emosi yaitu emosi positif dan emosi negatif, dan juga banyak mengalami emosi positif pada khususnya (Haybron, 2008). Siswa binaan di Lapas Tk.II Pekanbaru memiliki pemaafan dalam diri didukung oleh situasi Lingkungan selama berada di Lapas yaitu membangun hubungan emosi yang baik dengan rekan sesama siswa binaan.

Penelitian mengenai kebermaknaan hidup sebelumnya telah dilakukan Dewi dan Utami (2015) yang menjelaskan bahwa dukungan sosial menjadi salah satu faktor yang berpengaruh 
dalam kebermaknaan hidup. Feldman dan Steptoe (2003) menyatakan kemampuan individu dalam mengendalikan emosi mempengaruhi kebahagiaan, dimana yang menjadi faktor efektif untuk meningkatkan rasa kebahagiaan adalah faktor pengendalian emosi dan dapat mengurangi tingkat stress. Penelitian lain yang mengungkap mengenai kebermaknaan hidup adalah penelitian dari Lepistö et al., (2012), bahwa kebermaknaan hidup dipengaruhi oleh beberapa faktor di setiap remaja. Studi akhir-akhir ini menyoroti komponen kebermaknaan hidup paling banyak mempengaruhi pemaafan mungkin efek negatif dari kepuasan hidup. Ini berarti bahwa pemaafan mungkin menjadi salah satu jalan yang membantu untuk mengelola pengaruh efek maladaptif serta persepsi seseorang tentang hidupnya (Peterson, 2015). Hasil penelitiannya mengatakan bahwa remaja yang memiliki hubungan ibadah yang baik kepada Tuhan YME memiliki pengaruh positif terhadap hidupnya. Individu yang memiliki tingkat religiusitas tinggi lebih mampu memaknai hidupnya secara positif, sehingga hidupnya menjadi lebih bermakna dan terhindar dari stress maupun depresi (Saputri et al., 2013). Penelitian lain juga mengungkapkan pemaafan dan penerimaan diri memiliki pengaruh yang signifikan terhadap makna hidup pada individu dewasa awal (Rahmania et al., 2021).

\section{KESIMPULAN}

Berdasarkan hasil penelitian yang telah dilakukan maka dapat disimpulkan bahwa terdapat hubungan positif yang cukup signifikan antara pemaafan dengan kebermaknaan hidup pada siswa binaan di Lembaga Pemasyaratakatan Khusus Anak (LPKA) Tk.II di Kota Pekanbaru. Semakin baik pemaafan yang dimiliki oleh siswa binaan maka semakin baik pula kemampuannya dalam memaknai hidup. Hal ini menunjukkan bahwa remaja yang mampu memaafkan dirinya sendiri, memaafkan orang lain, dan memaafkan situasi dapat memaknai hidupnya dengan baik walaupun apa yang dialami mereka saat ini menjadi pengalaman buruk bagi kehidupan mereka. Ketika remaja mampu memaafkan, maka remaja diharapkan juga mampu merencanakan, mengarahkan, dan memonitor emosi, pikiran dan perilaku secara positif dalam menghadapi keadaannya sehingga dapat memperoleh kebahagiaan dan kepuasan dalam hidup dimasa yang akan datang.

\section{UCAPAN TERIMA KASIH}

Terimakasih yang sebesar-besarnya peneliti sampaikan kepada Kementerian Riset dan Teknologi / Badan Riset dan Inovasi Nasional Republik Indonesia yang telah memberikan kesempatan pada peneliti dan telah mendanai penelitian ini dengan maksimal sehingga peneliti dapat melaksanakan penelitian sebaik-baiknya. Peneliti juga berterimakasih pada Lembaga PeneLitian dan Pengabdian kepada Masyarakat (LPPM) Universitas Muhammadiyah Riau yang telah membimbing peneliti dan memberikan pengarahan secara jelas kepada peneliti mengenai pelaksanaan penelitian. Ucapan terimakasih juga peneliti sampaikan kepada anggota 1, anggota 2, mahasiswa serta seluruh pihak yang telah membantu proses pelaksanaan penelitian hingga penelitian ini dapat selesai dengan sangat baik. Terimakasih yang tak terhingga juga peneliti sampaikan untuk seluruh siswa binaan yang ada di Lapas Tk.II kota Pekanbaru yang sudah bersedia dengan sukarela menjadi subjek penelitian dan juga pihak-pihak pimpinan di Lapas yang telah menerima peneliti dengan baik.

\section{DAFTAR PUSTAKA}


Adista, D. (2015). Dampak Penempatan Anak di Lembaga Pemasyarakatan Berkaitan dengan Tujuan Pembinaan dalam Sistem Pemasyarakatan (Studi di Lembaga Pemasyarakatan Klas I Malang). Student Journal : Jurnal Hukum Universitas Brawijaya.

Afdal. (2010). Pelayanan konseling pada anak yang berhadapan dengan hukum. Seminar Nasional Psikologi Forensik, 24 November, 1-13.

Akhyar, Z., Matnuh, H., \& Najibuddin, M. (2014). Persepsi masyarakat terhadap mantan narapidana di desa benua jingah kecamatan barabai kabupaten hulu sungai tengah. Jurnal Pendidikan Kewarganegaraan, 4, 545-557.

Al-jauziyah, I. Q. (2005). Zikir Cahaya Kehidupan. Gema Insani.

American Psychological Association. (2006). Forgiveness : A Sampling of Research Results. Office of International Affairs.

Arista, D. (2017). Kebermaknaan hidup dan religiusitas pada mantan narapidana kasus pembunuhan (di kabupaten Paser). Psikoborneo, 5(3), 366-377. http://ejournal.psikologi.fisip-unmul.ac.id/site/wp-content/uploads/2017/11/JURNAL DWI ARISTA (11-27-17-03-00-11).pdf

Astuti, W., \& Marettih, A. K. E. (2018). Apakah Pemaafan Berkorelasi Dengan Psychological Well-Being Pada Remaja yang Tinggal Di Panti Asuhan? Jurnal Ilmu Perilaku, 2(1). https://doi.org/10.25077/jip.2.1.41-53.2018

Azani, A. (2012). Gambaran Psychological Well-Being Mantan Narapidana. EMPATHY Jurnal Fakultas Psikologi, Vol 1 No 2 Desember 2012. http://journal.uad.ac.id/index.php/EMPATHY/article/view/1409

Bastaman, H. D. (Hanna D. . (2007). Logoterapi : psikologi untuk menemukan makna hidup dan meraih hidup bermakna / H.D. Bastaman. Raja Grafindo Persada.

Brassai, L., Piko, B. F., \& Steger, M. F. (2011). Meaning in Life: Is It a Protective Factor for Adolescents' Psychological Health? International Journal of Behavioral Medicine, 18(1). https://doi.org/10.1007/s12529-010-9089-6

Damayanti, R. (2012). Gambaran Forgiveness Pada Remaja Yang Tinggal Di Panti Asuhan. Jurnal NOETIC Psychology, 2(2), 108-125.

Datu, J. A. D. (2014). Forgiveness, Gratitude and Subjective Well-Being Among Filipino Adolescents. International Journal for the Advancement of Counselling, 36(3), 262-273. https://doi.org/10.1007/s10447-013-9205-9

Dewi, P. S., \& Utami, M. S. (2015). Subjective Well-Being Anak Dari Orang Tua Yang Bercerai. Jurnal Psikologi, 35(2), 194 - 212-212. https://doi.org/10.22146/jpsi.7952

Evans, C., Ehlers, A., Mezey, G., \& Clark, D. M. (2007). Intrusive memories and ruminations related to violent crime among young offenders: phenomenological characteristics. Journal of Traumatic Stress, 20(2), 183-196. https://doi.org/10.1002/jts.20204

Feldman, P. J., \& Steptoe, A. (2003). Psychosocial and socioeconomic factors associated with glycated hemoglobin in nondiabetic middle-aged men and women. Health Psychology, 22(4), 398-405. https://doi.org/10.1037/0278-6133.22.4.398

Ferawati, \& Rahmandani, A. (2020). Hubungan Antara Pemaafan Diri Dengan Regulasi Emosi Pada Anak Didik Lembaga Pembinaan Khusus Anak (Lpka) Kelas I Kutoarjo Dan Kelas Ii Yogyakarta. Jurnal Empati, 8(3), 82-88.

Fristian, W., Darvina S, V. S., \& Sulismadi, S. (2020). Upaya Penyesuaian Diri Mantan Narapidana Dalam Menanggapi Stigma Negatif Di Kecamatan Klakah, Lumajang. ADLIYA: Jurnal Hukum Dan Kemanusiaan, 14(1), 101-120. https://doi.org/10.15575/adliya.v14i1.8205 
Glaz, S. (2019). The Relationship of Forgiveness and Values with Meaning in Life of Polish Students. Journal of Religion and Health, 58(5), 1886-1907. https://doi.org/10.1007/s 10943-019-00860-4

Haybron, D. (2008). Philosophy and the science of subjective well-being. In In M. Eid \& R. J. Larsen (Ed.), The science of subjective well-being (pp. 17-43). Guilford Press.

Lepistö, S., Joronen, K., Åstedt-Kurki, P., Luukkaala, T., \& Paavilainen, E. (2012). Subjective Well-Being in Finnish Adolescents Experiencing Family Violence. Journal of Family Nursing, 18(2), 200-233. https://doi.org/10.1177/1074840711435171

Lubis, S. M., \& Maslihah, S. (2012). Analisis Sumber-Sumber Kebermaknaan Hidup Narapidana Yang Menjalani Hukuman Seumur Hidup. Jurnal Psikologi Undip, 11(1), 12. https://doi.org/10.14710/jpu.11.1.12

McCullough, M. E. (2000). Forgiveness as Human Strength: Theory, Measurement, and Links to Well-Being. Journal of Social and Clinical Psychology, 19(1). https://doi.org/10.1521/jscp.2000.19.1.43

Nashori, F. (2011). Meningkatkan Kualitas Hidup dengan Pemaafan. Unisia, 33(75), 214 226. https://doi.org/10.20885/unisia.vol33.iss75.art1

Peterson, J. (2015). Examining the Relationship between Forgiveness and Subjective WellBeing as Moderated by Implicit Religiousness and Spirituality. https://digitalcommons.spu.edu/cpy_etd/3

Rahmania, F. A., Hizbullah, K., Anisa, S. N., \& Wahyuningsih, H. (2021). The Effects of Forgiveness and Self- Acceptance on the Meaning of Life in Early Adult Individuals with Divorced Parents: Pengaruh Pemaafan dan Penerimaan Diri terhadap Makna Hidup pada Individu Dewasa Awal yang Memiliki Orang Tua Bercerai. Proceding of Inter-Islamic University Conference on Psychology Articles, 1(1), 1-8.

Rey, L., \& Extremera, N. (2014). Positive psychological characteristics and interpersonal forgiveness: Identifying the unique contribution of emotional intelligence abilities, Big Five traits, gratitude and optimism. Personality and Individual Differences, 68, 199204. https://doi.org/10.1016/j.paid.2014.04.030

Santrock, J. (2019). Adolescence (seventeent). McGraw-Hill.

Santrock, J. . (2011). Child Development (Perkembangan anak Penerjemah : Rahmawati dan Kuswanti) (Edisi $11 \mathrm{~J})$. Erlangga.

Saputri, S. A., Hardjono, \& Karyanta, N. A. (2013). Hubungan antara religiusitas dan dukungan sosial dengan psychological well-being pada santri kelas viii pondok pesantren tahfidzul quran ibnu'abbas klaten.

Soleh, M. (2001). Kebermaknaan Hidup Mahasiswa Reguler Dan Mahasiswa Unggulan Universitas Islam Indonesia. Psikologika: Jurnal Pemikiran Dan Penelitian Psikologi, 6(11). https://doi.org/10.20885/psikologika.vol6.iss11.art6

Steger, M. F. (2010). The Meaning In Life Questionnaire (Mlq). Www.Michaelfsteger.Com. http://www.michaelfsteger.com/wp-content/uploads/2013/12/MLQ-description-scoringand-feedback-packet.pdf

Thompson, L. Y., Snyder, C. R., Hoffman, L., Michael, S. T., Rasmussen, H. N., Billings, L. S., Heinze, L., Neufeld, J. E., Shorey, H. S., Roberts, J. C., \& Roberts, D. E. (2005). Dispositional Forgiveness of Self, Others, and Situations. Journal of Personality, 73(2), 313-360. https://doi.org/10.1111/j.1467-6494.2005.00311.x

Toussaint, L., \& Webb, J. R. (2005). Theoretical and Empirical Connections Between Forgiveness, Mental Health, and Well-Being. In Handbook of Forgiveness. Routledge. 
https://doi.org/10.4324/9780203955673.ch21

UYSAL, R., SATICI, S. A., SATICI, B., \& AKIN, A. (2014). Subjective Vitality as Mediator and Moderator of the Relationship between Life Satisfaction and Subjective Happiness. Educational Sciences: Theory \& Practice. https://doi.org/10.12738/estp.2014.2.1828

Yalçın, İ., \& Malkoç, A. (2015). The Relationship Between Meaning in Life and Subjective Well-Being: Forgiveness and Hope as Mediators. Journal of Happiness Studies, 16(4). https://doi.org/10.1007/s10902-014-9540-5

Zuanny, I. P., \& Subandhi, S.-. (2017). Forgiveness therapy to increase the meaning of life among inmates in. Psikoislamedia: Jurnal Psikologi, 1(1). https://doi.org/10.22373/psikoislamedia.v1i1.1252 